ВИКЛАДАННЯ МЕДИЧНОЇ ТЕРМІНОЛОГІЇ ПІД ЧАС ВИВЧЕННЯ

АНГЛІЙСЬКОЇ МОВИ В УМОВАХ ДИСТАНЦІЙНОГО НАВЧАННЯ ЗА ДОПОМОГОЮ ПЛАТФОРМИ ДЛЯ ПРОВЕДЕННЯ ОНЛАЙН-ЗАНЯТЬ ZОOМ

\title{
TEACHING OF MEDICAL TERMINOLOGY DURING THE STUDY OF ENGLISH IN THE CONDITIONS OF DISTANCE LEARNING USING A PLATFORM FOR ONLINE CLASSES ZOOM
}

у статті проаналізовано методику викладання спеціальної медичної термінології для студентів вищих навчальних закладів на заняттях з англійської мови в умовах дистаниійного навчання. Освіта завжди має оперативно реагувати на актуальні тенденціі розвитку суспільства, адже тільки тоді вона зможе забезпечити її здобувачам можливість повноцінно жити та функціонувати в сучасному глобалізованому світі. Узагальнено досвід використання онлайн-платорорм під час навчання студентів у вітчизняних вищих навчальних закладах в умовах карантинних обмежень. Простежено шляхи створення нових комунікативних методик викладання фрахової мови на базі інтернет-платформ. При цьому встановлено, що найчастіше викладачі використовують для проведення лекційних та семінарських занять програмний додаток Zоом. 3 огляду на це було досліджено можливості використання платорорми для проведення онлайн-занять Zоом під час вивчення лексичного матеріалу в межах курсу з англійської мови для нефрілологічних спеціальностей медичних ЗВО. Зокрема, проаналізовано основний фуннціонал програми та можливості його використання на заняттях з метою кращого засвоєння студентами медичної термінології іноземною мовою. Визначено есрективні методи та прийоми навчання на уроках іноземної мови під час вивчення спеціальної термінології студентами медичних вищих навчальних закладів. Спрогнозовано, які методи та прийоми можна адаптувати та використовувати під час занять на платформі Zоом. Визначено форми організації навчального процесу, які $\epsilon$ найбільш есрективними під час вивчення медичної термінології студентами під час онлайн-занять. Узагальнено рекомендації для викладачів щодо організації навчального процесу в досліджуваному онлайн-середовищі, підбору методів і форм навчання, дидактичного та роздаткового матеріалу. Окреслено форми проведення онлайн-занять у Zоом, способи організації навчання та можливості платного $і$ безкоштовного використання додатку. З'ясовано, які труднощі можуть виникати під час вивчення спеціальних медичних термінів англійською мовою на дистаниійному навчанні, та запропоновано шляхи оптимізації цього процесу. Також вивчено світовий досвід використання інтернет-платформ для навчання студентів в онлайн-режимі.

Ключові слова: дистанційне навчання, медична термінологія, онлайн-заняття, платформа Zоом, вивчення англійської мови онлайн.

The article analyzes the method of teaching special medical terminology for students of higher educational institutions in English classes in terms of distance learning. The experience of using online platforms during students' education in higher education institutions in the conditions of quarantine restrictions is generalized. And most often teachers use the software application Zoom for lectures and seminars. Education must always respond quickly to current trends in society, because only then will it be able to provide its students with the opportunity to live and function fully in today's globalized world.

The subject of the study is an innovative method of conducting professional vocabulary through the viewing of authentic video segments. The issue of using medical videos as a lexical aspect of repetition learning is covered in this article. The possibilities of using the platform for online Zoom classes during the study of lexical material within the English language course for non-philological specialties of medical universities were explored. In particular, the main functionality of the program and the possibility of its use in the classroom in order to better master medical terminology by students in a foreign language are analyzed. Effective methods and techniques of teaching foreign language lessons during the study of special terminology by students of medical higher educational institutions are determined. It is predicted what methods and techniques can be adapted and used during classes on the Zoom platform. The forms of organization of the educational process that are the most effective in the study of medical terminology by students during online classes are identified. Recommendations for teachers on the organization of the educational process in the studied online environment, selection of methods and forms of teaching, didactic and handouts are summarized. Forms of conducting online classes in Zoom, ways of organizing training and the possibility of paid and free use of the application are outlined. Find out what difficulties may arise when learning special medical terms in English in distance learning and suggest ways to optimize this process. The world experience of using Internet platforms for teaching students online has also been studied. Key words: distance learning, medical terminology, online classes, Zoom platform, learning English online.
Постановка проблеми в загальному вигляді. Найбільшим викликом для світової спільноти останніх років стала пандемія, яка розпочалася 2019 року і так чи інакше вплинула на всі соціальні процеси, що відбуваються в сучасному світі.
Учасники освітнього процесу всіх рівнів за умов часткових або тотальних локдаунів змушені пристосовуватися до нового типу здобуття освіти дистанційного навчання. У досить короткий термін перед викладачами постало завдання організувати 
навчальний процес таким чином, щоб пандемія не вплинула на його якість і, тим паче, не призвела до повної зупинки навчання. Найкращим виходом у цій ситуації стало використання онлайн-платорорм та програмових додатків, які дали змогу організовувати для учнів та студентів повноцінні заняття 3 можливістю віртуальної присутності в режимі живого часу. 3 огляду на це методика викладання у вищій школі має започаткувати та активно розвивати якісно новий напрям наукових розвідок організацію дистанційного навчання та методику його проведення. Вивчення медичної термінології іноземною мовою вимагало підбору ефективних навчальних методик в умовах традиційного навчання, тому цю проблему висвітлювали у своїх наукових розвідках Ю. Блажевич, О. Петрова, Н. Попова та ін. На нашу думку, в теперішніх умовах варто розвивати цю тематику вже в контексті дистанційної форми здобуття освіти.

Мета статті - науково обґрунтувати методику використання платформи для проведення онлайн-занять Zоом під час вивчення спеціальної медичної термінології на заняттях 3 англійської мови; узагальнити рекомендації щодо організації навчального процесу в онлайн-середовищі для студентів закладів вищої освіти, зокрема на заняттях $з$ іноземної мови.

Виклад основного матеріалу. Для студентів немовних спеціальностей вивчення іноземної мови $€$ не менш важливим, ніж засвоєння спеціальних предметів. Англійська мова сьогодні $€$ не лише мовою інтернаціонального спілкування: в умовах пандемії знання англійської - це спосіб швидкого обміну досвідом та науковими відкриттями для лікарів з усіх країн, а також можливість для медиків отримати престижну роботу за кордоном. О. Петрова стверджує, що курс англійської мови професійного спрямування в медичному університеті включає медичну термінологію, оскільки це $є$ базовим для професійної діяльності. Саме навчання медичної термінології може стати позитивним аспектом в оволодінні іншомовним спілкуванням у спеціальності. У контексті вивчення англійської мови студентами-медиками актуальним завданням для них є знання медичних термінів та отримання навичок і вмінь використовувати спеціалізовану медичну лексику для виконання навчальних завдань, спрямованих на подальше професійне спілкування [2, с. 123].

Для студентів закладів вищої освіти в усьому світі використовуються такі популярні онлайнплаторорми: Docebo, Google Classroom, WizIQ, Adobe Captivate, Elucidat та ін. [7]. Аналіз педагогічного досвіду (власного, колег та відповідно до даних, взятих із мережі Інтернет) дає підстави стверджувати, що натепер однією 3 найпопулярніших платорорм для проведення онлайнзанять різних фрорм в Україні $€$ додаток Zoom.
Він надає можливість здійснювати відеоконореренції, онлайн-зустрічі, лекційні, групові та семінарські заняття, практикуми тощо.

Розглянемо більш детально фрункціонал цієї платорорми в контексті вивчення англійської мови студентами медичних вищих навчальних закладів в умовах дистанційного навчання:

1. Створення конореренцій. Для викладачів та студентів платорорма пропонує режими створення, планування, або можливість приєднатися до існуючої конференції. Це дозволяє викладачеві планувати заздалегідь час заняття, при цьому учасники майбутньої конореренції отримують посилання або код доступу, за яким вони можуть відвідати семінарське чи лекційне заняття.

2. Найефективнішим способом вивчення англійської медичної термінології дослідники і практики методики викладання вважають шлях через розуміння структури слова та значень частин слова, оскільки робота з медичною термінологією може бути порівняна з будівництвом споруди. Тому розпочинати знайомство з англійською медичною термінологією належить із базових мовних знань, а саме з нагадування про частини мови (nouns, verbs, pronouns, adverbs, and adjectives), актуальні для вивчення медичної термінології [6]. Для вивчення цього матеріалу можна використовувати міні-лекції з елементами наочності, яку викладач може розмістити на головному екрані за допомогою функціоналів, проаналізованих нижче.

3. Можливість одночасної демонстрації кількох екранів. Під час вивчення лексичного матеріалу на заняттях з іноземної мови візуалізація $€$ одним із найефективніших прийомів засвоєння навчального матеріалу. Готуючись до заняття, викладач зазвичай вибирає потрібні наочні матеріали, які використовує в ході опрацювання теми. Ïх можна організовувати у вигляді зображень, мультимедійних презентацій чи коротких відеороликів. Використання мультимедійних засобів навчання передбачає створення особливого типу мовленнєвих одиниць - полікодових текстів, які поєднують у собі знаки різних семіотичних систем. Мультимедіа - комбінування різних фрорм представлення інфрормації на одному носієві, сучасна комп'ютерна інформаційна технологія, що дозволяє об'єднувати в одній комп'ютерній програмнотехнічній системі текст, звук, відео, графрічне зображення, анімацію та мультиплікацію. Так, для роботи з термінами варто фокусувати увагу на обов'язковості запам'ятовування та повторювання («importance of learning by memorization and repetition» [2, с.124]). Для того щоб покращити запам'ятовування англійських термінів студентами, викладач може, наприклад, застосовувати різні кольори для презентації кожного виду частин слова (red for prefixes, blue for suffixes, green for word roots, and black for combining forms) [2, c. 124]). 
Тоді кожного разу, коли студент бачитиме колір, він асоціюватиме його з певною частиною слова. У сучасній методиці розроблені численні мнемонічні прийоми для вивчення медичної термінологіï. Так, можна ефективно використовувати mind maps, які слугують для візуалізаційної організації інорормації.

Оскільки вивчення термінології так чи інакше передбачає використання наочності, одним із найзручніших фрункціоналів програми Zoom у цьому контексті $€$ можливість відкриття одночасно кількох вікон на головному екрані, а також демонстрація окремих вікон і перемикання між ними під час проведення заняття. Так, іноземні педагоги стверджують, що для кращого засвоєння медичні терміни варто поділяти на частини - структурні одиниці. Ці частини, як правило, становлять собою комбінацію кореневого слова (основа слова), префрікса (перших кількох букв слова) та сусрікса (закінчення слова). Розбиття слів таким чином зменшує об'єм запам'ятовування, що полегшує засвоєння термінів англійською. 3 цією метою викладачеві доцільно використовувати графічні схеми й таблиці, підготовлені заздалегідь. Функція демонстрації екрану дозволяє виводити ці таблиці «у загальне поле» заняття, коментувати та аналізувати їх. При цьому корисним інструментом може стати олівець. Під час демонстрації екрану є можливість коментувати (Co-annotation), тобто можна малювати, виділяти, витирати тощо. Це може робити як викладач, так і студенти (якщо дана фрункцію дозволена викладачем) [5].

4. Під час вивчення іноземної термінології важливим $€$ не тільки засвоєння морфології, граматики й орфографії, а й фронетичне звучання кожного слова. У цьому плані корисною є можливість платорорми Zoom відтворювати відео- та аудіофайли прямо під час заняття. Крім того, студенти можуть по черзі потренувати вимову під керівництвом викладача - для цього досить натиснути на значок «піднята рука», і викладач побачить, який саме зі студентів бажає висловитися, щоб надати йому слово. Окрім того, щоб більше зрозуміти структуру та походження слова, є кілька прийомів запам'ятовування, які викладач може використовувати під час онлайн-навчання за допомогою фрункціоналів Zoom.

Поєднання візуальних образів із новими термінами за допомогою техніки асоціацій. Вивчаючи медичну термінологію, за допомогою зображень чи в презентації викладач може поєднати слово із зображенням, якому воно відповідає. Крім того, можна використовувати не статичні, а рухомі зображення різних фрорматів, таких як Гіфрф. Такі ілюстрації виглядатимуть нестандартно і, відповідно, краще запам'ятовуватимуться. Їх також можна використовувати під час заняття за допомогою фрункції «демонстрація екрану».
Флеш-картки - це перевірений спосіб вивчити нові слова та поняття іноземною мовою. Написання терміна, який потрібно вивчити, з одного боку, та визначення, з іншого боку, може бути корисним прийомом запам'ятовування. Щоб створити цифровий фрормат фрлеш-карток, викладач може використовувати безліч навчальних програм, таких як Ankidroid, StudyDroid, Dictonary.com Flashcards, Chegg Flashcards i StudyBlue [4]. Створення фрлеш-карт може бути однією із фрорм домашнього завдання для студентів. Демонструвати виконане завдання студенти можуть по черзі з використанням функції «піднята рука» - такого собі аналогу відповіді біля дошки перед аудиторією.

5. Одним з обов'язкових етапів вивчення медичної термінології на заняттях з англійської мови $€$ виконання студентами вправ і практичних занять. Якщо під час традиційного навчання викладач міг контролювати цей процес протягом заняття, в умовах дистанційного такої можливості практично немає. Частково здійснювати таку фрорму роботи в Zoom можна за допомогою чатів. Викладач може надіслати студентам для виконання заздалегідь підготовлені практичні завдання, а студенти можуть їх викладати до загального чату або надсилати викладачеві у приватному повідомленні.

Безперечно, вивчення медичних термінів на заняттях з англійської мови у Zoom вимагає ретельної підготовки саме від викладача. Для оптимізації цього процесу ми узагальнили та систематизували практичні рекомендації щодо організації навчального процесу онлайн, зокрема для підготовки занять з вивчення медичної термінології.

Планувати час і фрорму проведення заняття варто заздалегідь. Для цього треба вибрати у Zoom функцію планування конференції і надіслати студентам повідомлення 3 посиланням на кабінет і точним часом проведення заняття. Робити це варто з урахуванням календарно-тематичного планування, узгодивши графрік навчання з іншими викладачами. Крім того, варто врахувати час, потрібний для виконання студентами індивідуальних завдань, які теж варто розіслати заздалегідь.

Варто використовувати шаблони дистанційного навчання, щоб допомогти в організації загального курсу. Для вивчення термінології варто використовувати оригінальні фрорми подання лекційного матеріалу (наприклад, попередньо записане відео, презентації Power Points або конспекти лекцій), дописи в блозі, короткі аудіо- чи відеофрагменти, приклади роботи тощо.

Варто створювати 5-10-хвилинні міні-лекції (менше 500 МБ), що зосереджуються на окремих блоках вивчення лексичного матеріалу (відповідно позначених, щоб студенти могли їх легко знайти для навчальних цілей); ця тривалість відповідає тривалості уваги, обмеженням зв'язку та мінливості часу для перегляду матеріалу студентами. 
Зробити чіткими зв'язки між результатами навчання, темами й методами навчання, щоб допомогти студентам структурувати свою увагу.

Відпрацьовувати корисні звички студентів під час заняття, наприклад, робити перерви під час прослуховування теоретичного матеріалу, щоб підсумувати свої замітки та визначити запитання, які потрібно поставити чи опублікувати.

Варто забезпечити студентам вільність та гнучкість, дозволивши їм виконати підгрупу завдань під час заняття. Варто активізувати діяльність студентів у ході заняття, щоб дозволити застосувати набуті вміння та оцінити своє розуміння. Варто також ураховувати час, необхідний для виконання цих заходів, у плануванні робочого навантаження.

Важливо забезпечити доступність навчального матеріалу, щоб студенти могли переглянути його перед або після заняття, перевірити своє розуміння, коли новий матеріал ґрунтуються на попередніх знаннях.

Треба давати студентам достатньо часу між розміщенням матеріалів та кінцевими термінами для їх виконання.

Можна активно використовувати під час заняття чат, який дозволяє всім студентам взаємодіяти, брати участь у роботі над вивченням нових термінів та бачити роботу одногрупників.

Варто враховувати, що колективна робота може бути надзвичайно складною для студентів в Інтернеті, тому треба чітко визначити рекомендації, як виконувати групову роботу асинхронно, зокрема 3 використанням випереджувальних завдань.

Наостанок варто зазначити, що онлайн-платформа Zoom пропонує для своїх користувачів два способи використання - безкоштовний і платний. Безкоштовне заняття може тривати протягом 40 хвилин, що відповідає тривалості академічної години. Такий варіант є досить зручним для викладача, оскільки він отримує можливість організувати повноцінне заняття зі студентами без додаткових матеріальних витрат.

Висновки. Сучасна освіта розвивається за досить складних обставин, які спричинило поширення пандемії. За таких умов навчання студентів вимагає нових фрорм і методів організації навчання, що дають змогу здійснювати дистанційне навчання онлайн. Вивчення медичної термі- нології студентами на заняттях 3 англійської мови передбачає системну роботу 3 використанням різних видів наочності та виконання практичних завдань. Вирішити ці навчальні задачі можна 3 використанням онлайн-платорорм, зокрема таких, як Zoom. Ця програма містить необхідний набір інструментів, що дають можливість організувати повноцінне заняття з вивчення медичної термінології, таких як: можливість попереднього планування, демонстрація екрану, функція «олівець», відтворення аудіо- та відеофайлів, спілкування в чаті, фрункція «піднята рука» та ін. Безперечно, такі заняття вимагають ґрунтовної підготовки як з боку викладача, так і студентів. Саме тому перспективним є напрям методологічних досліджень, що полягає у створенні системи вправ, матеріалів та готових шаблонів і кейсів для проведення таких занять.

\section{БІБЛІОГРАФІЧНИЙ СПИСОК:}

1. Блажевич Ю. Наскільки важлива англійська в медицині? URL: https://yappi.com.ua/ua/posts/read/ anglijskij-v-medicine-osobennosti-terminologiya-isamostoyatelnoe-izuchenie

2. Петрова О.Б., Попова Н.О. До питання про навчання англійської медичної термінології. Проблеми та перспективи розвитку науки на початку третього тисячоліття у країнах Європи та Азії : матеріали XVI Міжнародної науково-практичної інтернет-конореренції (1-2 серпня 2015 р.). Збірник наукових праць. Переяслав-Хмельницький, 2015. C. $123-125$.

3. 3 Tips for Memorizing Medical Terminology in Your Health Administration Courses. URL: https:// canadianbusinesscollege.com/2019/10/18/3-tipsfor-memorizing-medical-terminology-in-your-healthadministration-courses/

4. 6 Ways to Learn Medical Terminology. URL: https://www.bryantstratton.edu/blog/2015/december/ keys-to-learning-medical-terminology

5. Green Forest. Інструкція для студентів Green Forest по користуванню. URL: Zoom//https:// greenforest.com.ua/ua/journal/read/instrukciya-dlyastudentov-green-forest-po-polzovaniyu-zoom

6. Lynette M. Veach, Marsha M. Holtsberry. Medical Terminology. Pearls of Wisdom. Pearson Education, 2009.

7. Dalton W., Turner B. Best online learning platforms of 2020: LMS and VLE for education. URL: https:// www.techradar.com/best/best-online-learning-platforms 